\title{
Tracing metal concentrations in egg strings of sea hare, Dolabella auricularia from Pujada Bay
}

\author{
Janeth C. Tayone* \\ Institute of Agriculture and Life Sciences, Davao Oriental State College of Science and Technology, City of Mati, 8200, Davao \\ Oriental, Philippines
}

\section{A R T I C L E I N F O}

\section{Article history:}

Received 27 October 2016

Received in revised form

14 February 2017

Accepted 14 February 2017

\section{Keywords:}

Dolabella auricularia

Egg strings

Pujada Bay

Sea hare

Trace metal

\begin{abstract}
A B S T R A C T
The egg strings of sea hare, Dolabella auricularia are economically important to the local fisher folks in Davao Oriental. These are gathered for food consumption or sold in the market. The province of Davao Oriental is one of the country's tourist destinations. Increasing anthropogenic activities are inevitable which can contribute to the levels of trace metal concentrations in the area. The primary purpose of this study was to determine the concentrations of $\mathrm{Fe}, \mathrm{Zn}, \mathrm{Cd}, \mathrm{Hg}$ and $\mathrm{Pb}$ using atomic absorption spectrophotometer. Trace metals average concentrations in egg strings were found to be $175.67 \mu \mathrm{g} \mathrm{g}^{-1}$ for Fe, $282.00 \mu \mathrm{g} \mathrm{g}^{-1}$ for $\mathrm{Zn}, 0.98 \mu \mathrm{g} \mathrm{g}^{-1}$ for Cd, 0.01

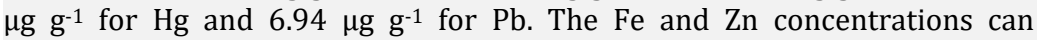
supplement the body's requirement needed for normal growth and development based on the Recommended Energy Nutrient Intakes for Filipinos. Moreover, the mercury concentration was lower than the existing standard set by FAO No. 21 of 2001. However, the amount of $\mathrm{Cd}$ and Pb were noticeably higher than the maximum level. This investigation represents the first study so far on the levels of trace metals in egg strings of sea hare from Pujada Bay, Davao Oriental. The results of this study provide baseline information for the conduct of further investigation to monitor and evaluate the trace metal concentrations and the contributing anthropogenic activities. These will help the local government in the formulation of policies for a sustainable development.
\end{abstract}

(c) 2017 The Authors. Published by IASE. This is an open access article under the CC BY-NC-ND license (http://creativecommons.org/licenses/by-nc-nd/4.0/)

\section{Introduction}

The sea hare, Dolabella auricularia is a softbodied marine organism that belongs to Phylum Mollusca. The scientific name Anaspidea comes from the Greek word "without shield" (Simmons et al., 2005). They lack protective shell to protect themselves. However, it releases a copious ink to deter their predators. Sea hares are nocturnal. Feeding, mating and spawning activities can be observed from late afternoon to early morning during the lowest tide (Calumpong, 1979). In the study area, sea hares measure 5 to 7 inches and weigh approximately 500 grams with colors ranging from green, black and red (Fig. 1). It can lay millions of eggs strings or egg masses which are locally known as "lukot". Egg strings from sea hares are economically important in the Philippines. These are

\footnotetext{
* Corresponding Author.

Email Address: njtayone2005@yahoo.com

https://doi.org/10.21833/ijaas.2017.02.022

2313-626X/C) 2017 The Authors. Published by IASE.

This is an open access article under the CC BY-NC-ND license

(http://creativecommons.org/licenses/by-nc-nd/4.0/)
}

sources of food for marginalized local fisher folks. Egg strings are either eaten raw served as a salad or cooked. It has become one of the Filipino's delicacies. Further, it is also being sold in the market to augment their income. This utilization of egg strings are not only known in the Philippines but in other countries like Samoa, Kiribati and Fiji Island (Singh and Vuki, 2009).

The province of Davao Oriental is a tourist destination in Southeastern Mindanao, Philippines. The influx of tourist in the province of Davao Oriental in addition to small and large- scale mining has increased anthropogenic activities in the area that can contribute to the increasing levels of trace and heavy metals in the water and sediments. Naturally, trace elements can enter the marine ecosystem through weathering and erosion. However, its concentration increases when industrial wastes or sewage are introduced and enters the biogeochemical process which will make it potentially toxic and may interfere with the normal ecology of a certain environment (Bryan, 1971). The toxicity of a certain metal is not related to the accumulated concentration, but on the threshold 
of metabolically available metal concentration. Its detrimental effects will be apparent at higher level (Rainbow, 2002). Trace metal concentrations increase at first along the food chain and maximum concentration is exhibited by crustaceans and decreases in fishes. Trace metals such as iron (Fe), zinc ( $\mathrm{Zn})$, mercury $(\mathrm{Hg})$, lead (Pb) and cadmium (Cd) are normal composition of marine and estuarine environment. Iron and zinc are essential for normal physiological processes in humans. However, the excess amount may have adverse health effects and may lead to toxicity. On the other hand, metals such as mercury, cadmium and lead are classified as nonessential and are toxic even in trace amounts (Jinadasa et al., 2014).

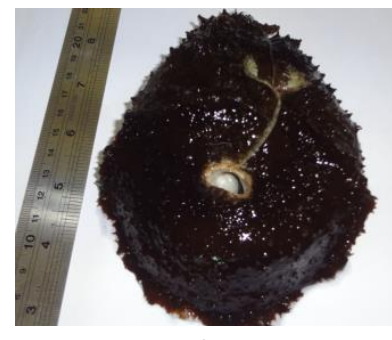

a

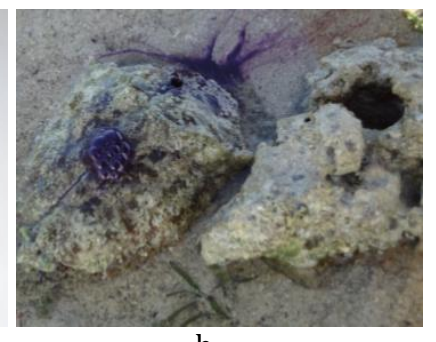

b
Fig. 1: The sea hare Dolabella auricularia, black (a) and green (b) collected from Pujada Bay, City of Mati, Davao Oriental, Philippines

Sea hare, a gastropod and a number of marine organisms are reported to accumulate metals in their bodies (Xing and Chia, 1997). The heavy metal accumulation is said to be positively correlated with the metal concentration in their diet and ambient water and sediments. The latter is considered as a heavy metal reservoir since sediment particles can trap the trace metals (Julshamn and Grahl-Nielsen, 1996). There are several studies that show the vast range of accumulated trace metal concentrations in aquatic invertebrates. This depends on the accumulation pattern of a particular marine organism for a specific trace metal. The biological importance of trace metal concentration in a certain invertebrate provides information, whether it is high or low and the biological changes of the invertebrates or the variation in geographical or temporal bio availabilities of toxic metals in aquatic systems (Rainbow, 2002). The study of Jinadasa (2014) showed that the concentration of trace metals in the squids and cuttlefish from the NorthWestern Sea of Sri Lanka is within the international safety limits. The levels of trace metals in two marine bivalve mollusks from the Southern Spain were found to be suitable for human consumption, according to Spanish legislation (Usero et al., 1997). While the levels of arsenic and lead in two cucumber species from Malaysia are higher than Malaysian Food Act of 1993 which resulted in the exclusion of these two cucumber species for exportation (Hashmi et al., 2014).

The primary purpose of this study was to determine quantitatively the concentration of trace metals ( $\mathrm{Fe}, \mathrm{Zn}, \mathrm{Cd}, \mathrm{Hg}$ and $\mathrm{Pb}$ ) in the egg strings of
Dolabella auricularia from Pujada Bay, City of Mati, Davao Oriental. The results of this study determine if the egg strings of sea hare are suitable for human consumption based on its metal concentration in the area studied. This provides baseline information for the local government, Department of Environment and Natural Resources (DENR) and Bureau of Fisheries and Aquatic Resources (BFAR) in monitoring and evaluating the levels of heavy metals and bases for formulating policies for a sustainable development.

\section{Materials and methods}

\subsection{Sampling site}

The study site was in Guang-guang Cove, Pujada Bay, City of Mati, Davao Oriental (Fig. 2). These were the coordinates where the samples were taken: $1 . \mathrm{N}$ 06 55'25.9" E126015"30.0"; 2. N 06 $54^{\prime \prime} 51.4^{\prime \prime}$ E12614"26.8"; 3. N 0654'48.4" E12614"28.5". The area included a fishing ground and a stretch of mangrove reforestation. The sea bed was sandymuddy with an abundant sea grasses making it more preferable by the burrowing mollusk like sea hare. The absence of an extreme low tide in the area made it a productive and therefore, a rich marine resource.

\subsection{Collection and preparation of samples}

Three sets of egg strings samples (bunch of egg strings) were randomly collected in the surrounding area. Samples were placed in a plastic container with seawater and the temperature was maintained at 4 ${ }^{\circ} \mathrm{C}$ during its transportation to the laboratory. The egg strings were cleaned and cut into pieces about half an inch and drained for 10 minutes.

\subsection{Total $\mathrm{Fe}, \mathrm{Zn}, \mathrm{Cd}, \mathrm{Hg}$ and $\mathrm{Pb}$ content}

One gram of sample was weighed accurately, dried and ground in high-form porcelain crucible. It was placed in a muffle furnace with the temperature slowly raised to $500{ }^{\circ} \mathrm{C}$ for 4 hours or until the ash became white and then cooled. The ash was moistened with $1 \mathrm{~mL}$ distilled water and carefully added with 3-4 $\mathrm{mL} \mathrm{HNO}_{3}$. Excess nitric acid was removed by evaporation on a hot plate that was set at 100 to $120^{\circ} \mathrm{C}$. It was then transferred into a $50 \mathrm{~mL}$ volumetric flask and diluted to mark with distilled water. The solution was used for the determination of $\mathrm{Fe}, \mathrm{Zn}, \mathrm{Cd}, \mathrm{Hg}$ and $\mathrm{Pb}$ using Atomic Absorption Spectrophotometer (AOAC, 2002). Three trials were done for each egg strings sample.

\section{Results and discussion}

The trace metal concentrations in the egg strings of sea hare are summarized in Table 1. Zinc had the highest mean concentration of $282.00 \mu \mathrm{g} \mathrm{g}^{-1}$ followed by iron with $175.67 \mu \mathrm{g} \mathrm{g}^{-1}$. Among the non- essential heavy metals ( $\mathrm{Cd}, \mathrm{Hg}$ and $\mathrm{Pb}$ ), $\mathrm{Pb}$ had the highest 
concentration of $6.94 \mu \mathrm{g} \mathrm{g}-1$ followed by cadmium with $0.98 \mu \mathrm{g} \mathrm{g}^{-1}$ and lastly, mercury with $0.01 \mu \mathrm{g} \mathrm{g}^{-1}$ only. While there are a lot of studies conducted for the trace metals and heavy metals accumulation in marine organisms such as mollusks using the different parts like viscera, muscles and other tissues, less information are found for sea hare, Dolabella auricularia specifically on its egg strings.
Hence, the results were compared to a study on the mollusks that generally represent marine organisms and to other species of sea hare, Aplysia californica. Furthermore, Fisheries Administration Order (FAO), No. 210 of 2001 (FAO, 2001) standard and Recommended Energy Nutrient Intakes (RENI) for Filipinos were also used in comparing the values obtained in this present study.

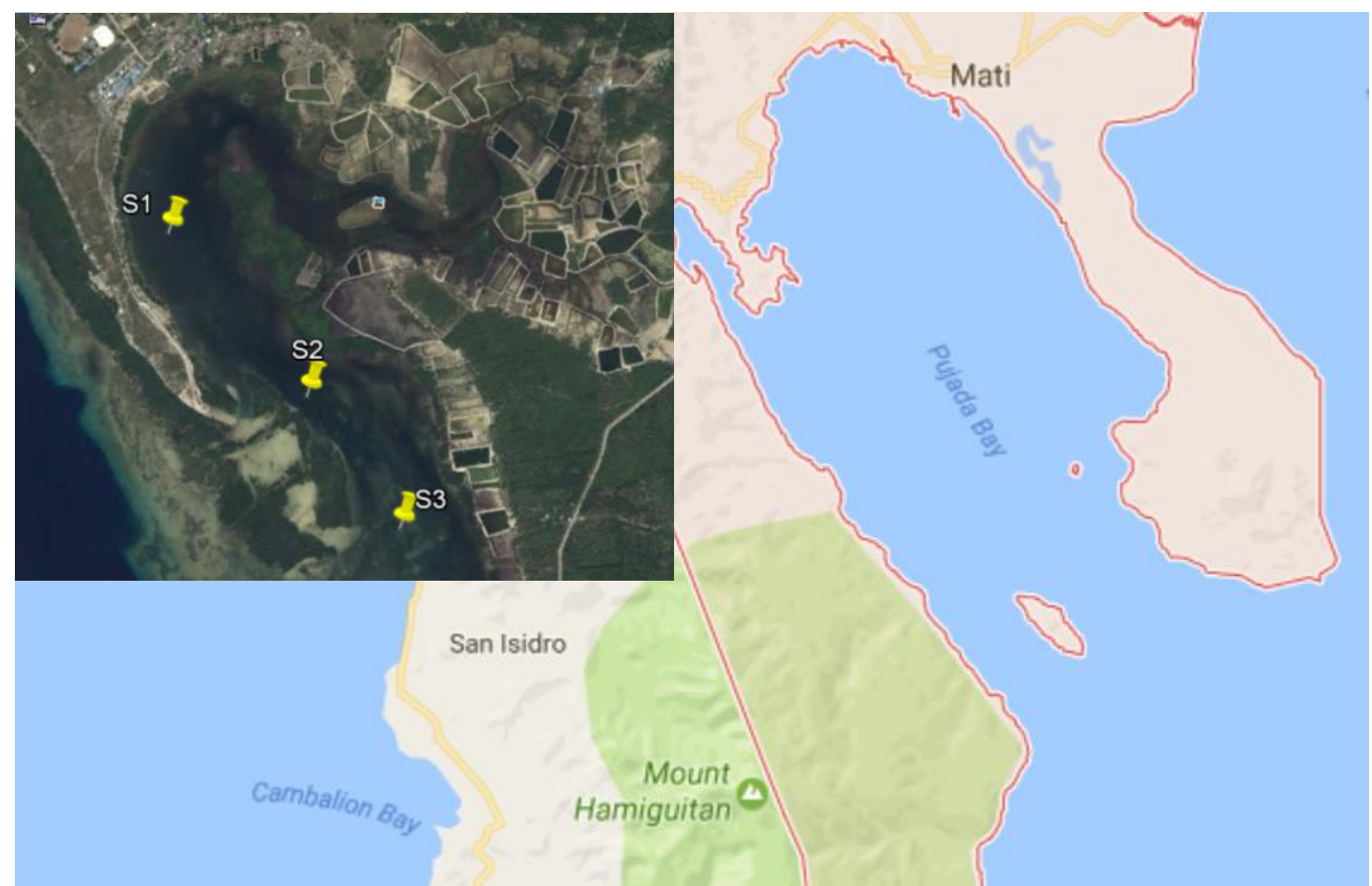

Fig. 2: The map of the sampling site located at Pujada Bay, City of Mati, Davao Oriental, Philippines

Table 1: Mean concentrations of trace metals in an egg strings sample of Dolabella auricularia

\begin{tabular}{cccccc}
\hline \multirow{2}{*}{ Trace Metal } & \multicolumn{3}{c}{ Sample } & \multirow{2}{*}{ Mean Concentration } & FAO (2001) \\
\cline { 2 - 4 } & $\mathrm{S}_{1}$ & $\mathrm{~S}_{2}$ & $\mathrm{~S}_{3}$ & & 175.67 \\
$\mathrm{Fe},\left(\mu \mathrm{g} \mathrm{g}^{-1}\right)$ & 193 & 139 & 195 & 282.00 & 0.5 \\
$\mathrm{Zn},\left(\mu \mathrm{g} \mathrm{g}^{-1}\right)$ & 584 & 119 & 143 & 0.98 & 0.5 \\
$\mathrm{Cd},\left(\mu \mathrm{g} \mathrm{g}^{-1}\right)$ & 0.74 & 1.30 & 0.90 & 0.01 & 0.5 \\
$\mathrm{Hg},\left(\mu \mathrm{g} \mathrm{g}^{-1}\right)$ & 0.01 & 0.01 & 0.01 & 6.94 & \\
$\mathrm{~Pb},\left(\mu \mathrm{g} \mathrm{g}^{-1}\right)$ & 5.62 & 7.34 & 7.87 & Analyses of each sample $(\mathrm{S})$ were done in three replicates
\end{tabular}

The concentration of $\mathrm{Fe}$ in the egg strings had a ranged of 139 to $193 \mu \mathrm{g} \mathrm{g}^{-1}$. These were higher than the Fe content in the squids ( $L$. duvauceli, $S$. lelssoniana and S. latimanus) with a range of 1.03 ppm to $3.32 \mathrm{ppm}$ as studied by Jinadasa (2014). Another study conducted by Jinadasa et al. (2014) on ten different sea cucumbers showed Fe content ranging from $5.03 \mathrm{ppm} 56.68 \mathrm{ppm}$. The result of $\mathrm{Fe}$ content in this study was comparable to the iron content of two bivalve mollusks (Ruditapes decussates and Ruditapes philippinarium) as studied by Usero et al. (1997). The present study showed that the egg strings are a good source of Fe needed by the human body. According to the Recommended Energy Nutrient Intakes (RENI) for Filipinos, women need $27 \mathrm{mg}$ daily while the men's requirement is only $12 \mathrm{mg}$. The higher requirement for women is based on the needed amount to cover the Fe losses during menstrual and reproductive age of women. This required amount can be supplemented by making egg strings a part of once diet (Barba and Cabrera, 2008).
The mean concentration of $\mathrm{Zn}$ was $282 \mu \mathrm{g} \mathrm{g}^{-1}$. Zn is an essential nutrient and generally, its concentrations are higher in mollusk compared to other seafood. Mollusks and other gastropods can accumulate $\mathrm{Zn}$ from the environment and its diet (Saleh et al., 2011; Jarvis et al., 2015). A study on the level of zinc in three different species of squid shows that it ranges from 3.52 to $42.41 \mathrm{ppm}$. Its concentration also varies in the different organs in this particular order; liver $>$ skin $>$ gills $>$ tentaclesmuscles. An increase in $\mathrm{Zn}$ accumulation in the different parts of Aplysia californica is also reported by Jarvis et al. (2015) after exposing it to a metal diet. Zinc accumulation was also observed in the gonads of sea urchin after metal dietary exposure and even in the gonads of other marine fishes. These are found in high concentration in male reproductive organs which plays a very important role in the formation and maturation of sperm as well as ovulation and fertilization. Furthermore, zinc is one of those metals that binds with metallothionein with homeostasis function and plays a role in the 
detoxification of the non-essential metals (Jinadasa, 2014).

The levels of cadmium in the egg strings ranged from $0.7 \mu \mathrm{g} \mathrm{g}^{-1}$ to $1.3 \mu \mathrm{g} \mathrm{g}^{-1}$. These values were higher than the maximum level of 0.5 ppm set by FAO (2001). Jarvis et al. (2015) reported that cadmium readily accumulates in many organs of the sea hare, Aplysia californica. These accumulations are dependent on the concentration of cadmium in the treated sea grass which they are being fed in. Accumulated $\mathrm{Cd}$ in the eight species of cucumber was also studied by Jindasa, and showed that the $\mathrm{Cd}$ concentration ranges between $0.04 \mu \mathrm{g} \mathrm{g}^{-1}$ to $0.137 \mu \mathrm{g}$ $\mathrm{g}^{-1}$. While another study shows the Cd concentration of $0.07 \mu \mathrm{g} \mathrm{g} \mathrm{g}^{-1}$ to $0.42 \mu \mathrm{g} \mathrm{g}^{-1}$ in bivalve mollusks (Usero et al., 1997). Ray and Kiceniuk (1994) reported that the bioaccumulation of cadmium among marine organisms is in the order of mollusk, crustaceans and fish and is dependent on the metal pollution from anthropogenic activities. The possible cause of high Cd level in this study might be due to farming activities in the nearby area. The use of agricultural products like fertilizer has contributed to higher levels of cadmium in the sampling site (Ray, 1984). Cadmium has gained more attention because of its biopersistency, cumulative effects and toxicity to the consumer (Jinadasa, 2014).

The amount of $\mathrm{Hg}$ proved to be non-alarming because the measured value was $0.01 \mu \mathrm{g} \mathrm{g}^{-1}$ only. This value was lower than the standard for fishery products of $0.5 \mathrm{mg} / \mathrm{kg}$ set by FAO No. 210. The same maximum permissible concentration of $\mathrm{Hg}$ is followed in other European countries for edible fishery products. While in Spain, the maximum allowed concentration of $\mathrm{Hg}$ in mollusk is $1 \mathrm{ppm}$ (Usero et al., 1997). Accordingly, the entry point for methyl mercury in the food chain is thru the filter feeding organisms and increases in concentration as it goes up the food chain. Naturally, $\mathrm{Hg}$ can be deposited in the sediments which can be taken by direct assimilation of marine burrowing mollusk like sea hare (Jinadasa et al., 2014). Recently, mercury is one of the most studied heavy metals because of its bioaccumulations and biomagnification in the food web. Its deleterious effects on the central nervous system affect cell division. Some studies show that mercury concentration can vary according to the location as well as the depth of the sampling area (Michel et al., 2006; Jinadasa, 2014).

Lead is one of the nonessential metals. Its mean concentration in the egg strings was $6.94 \mu \mathrm{g}^{-1}$. This concentration was higher than the maximum level of 0.5 ppm set by FAO (2001). However, the Pb level in the egg strings was lower compared to the study of Laskowski and Hopkin (1995) with $\mathrm{Pb}$ concentrations ranging from 21 to $156 \mathrm{mg} / \mathrm{kg}$ in $H$. adspersa and so with Aplysia californica with a range of 2.5 to $300 \mathrm{mg} / \mathrm{kg}$. It is also shown that the $\mathrm{Pb}$ accumulation differs in the organs of sea hare, Aplysia californica after a metal dietary exposure (Jarvis et al., 2015). Various anthropogenic activities may have greatly influenced the result of this present study. Fishing boats that discharge or cause oil spills, domestic sewage, mining, fossil fuel combustion and water runoff may have contributed to this high level (Mance, 1987). Marine gastropods like sea hare are known to accumulate high concentration of metals in their digestive organs (Wang and Ke, 2002). This is attributed to the binding and storing capability of their spherical and intracellular granules (Gibbs et al., 1998). High Pb content can be physiologically deleterious to organisms. Humans taking high levels of lead from their food can result to kidney dysfunction, damages the brain and inhibits enzyme functions (Jinadasa, 2014).

\section{Conclusion}

This study is the first attempt to establish the trace metal concentrations in egg strings of sea hare, Dolabella auricularia from Pujada Bay, Davao Oriental. The results showed that egg strings is a good source of the essential elements Fe and $\mathrm{Zn}$ needed by the body. However, the levels of the nonessential heavy metals ( $\mathrm{Cd}$ and $\mathrm{Pb}$ ) except for $\mathrm{Hg}$ exceeded the standard set by FAO 210. This study provides baseline information that will be the basis for the conduct of another study to verify, monitor and evaluate the levels of such heavy metals in sea hare resource and its ambient environment. These data will help the concern agencies in evaluating anthropogenic activities that had contributed to the noticeable amount of $\mathrm{Cd}$ and $\mathrm{Pb}$. Furthermore, it can be a basis for the formulation of policies for a sustainable environment.

\section{Acknowledgement}

The author would like to acknowledge the Research, Development and Extension Division of Davao Oriental State College of Science and Technology for providing the funds for this study.

\section{References}

AOAC (2002). Official Methods of Analysis. 17th Edition, Association of Official Analytical Chemists, Arlington, Virginia 22201 USA.

Barba CVC and Cabrera MIZ (2008). Recommended energy and nutrient intakes for Filipinos 2002. Asia Pacific Journal of Clinical Nutrition, 17(S2): 399-404.

Bryan GW (1971). The effects of heavy metals (other than mercury) on marine and estuarine organisms. Proceedings of the Royal Society of London B: Biological Sciences, 177(1048): $389-410$

Calumpong HP (1979). Some aspects of ecology of sea hare Dolabella auricularia (Lightfoot), in the central Philippines. Silliman Journal, 26: 134-146.

FAO (2001). Rules and regulations on the exportation of fresh, chilled and frozen fish and fishery/aquatic products. Fisheries Compilation of Fisheries Administrative Orders Series of 2000-2001: 88-92. Available online at: www.fao.org/fishery/ legalframework/nalo_philippines/en

Gibbs PE, Nott JA, Nicolaidou A, and Bebjanno MJ (1998). The composition of phosphate granules in the digestive glands of 
marine prosobranch gastropods: variation in relation to taxonomy. Journal of Molluscan Studies, 64(4): 423-433.

Hashmi MI, Thilakar R, Husein MAS, and Hoque Z (2014). Determination of seven heavy metals in eight species of sea cucumbers. Science International (Lahore), 26(1): 261-262.

Jarvis TA, Capo TR and Bielmyer-Fraser GK (2015). Dietary metal toxicity to the marine sea hare, Aplysia californica Comparative Biochemistry and Physiology Part C: Toxicology \& Pharmacology, 174: 54-64.

Jinadasa BKKK (2014). Concentration of trace metals in the squids (Loligo duvauceli, Sepiotethis lessonina) and cuttlefish (Sepia latimanus) from the North-Western Coast of Sri Lanka. Journal of Aquatic Science, 2(2): 5-10.

Jinadasa BKKK, Samanthi RI, and Wicramsinghe I (2014). Trace metal accumulation in tissue of sea cucumber species; Northern-Western Sea of Sri Lanka. American Journal of Public Health Reseach, 2(5A): 1-5.

Julshamn K and Grahl-Nielsen 0 (1996). Distribution of trace elements from industrial discharges in the Hardangerfjor, Norway: a multivariate data analysis of saithe, flounder and blue mussel as sentinel organisms. Marine Pollution Bulletin, 32(7): 546-571.

Laskowski R and Hopkin SP (1995). Effect of $\mathrm{Zn}, \mathrm{Cu}, \mathrm{Pb}$, and $\mathrm{Cd}$ on fitness in snails (Helix aspersa). Ecotoxicology and Environmental Safety, 34(1): 59-69.

Mance G (1987). Pollution Threat of Heavy Metals in Aquatic Environments. Elsevier Science Pub. Co. Inc., New York, USA.

Michel W, Sandrine D, Gilles L, Alessia M, Rodrigues Y, and Philippe D (2006). Heavy metals in the sea cucumber Holothuria tubulosa (Echinodermata) from the Mediterranean Posidonia oceanica ecosystem: body compartment, seasonal, geographical and bathymetric variations. Environmental Bioindicators, 1(4): 268-285.

Rainbow PS (2002). Trace metal concentrations in aquatic invertebrates: why and so what?. Environmental Pollution, 120(3): 497-507.

Ray S (1984). Bioaccumulation of cadmium in marine organisms. Cellular and Molecular Life Sciences, 40(1): 14-23

Ray S and Kiceniuk JW (1994). Analysis of contaminants in edible aquatic resources: general considerations, metals, organometallics, tainting, and organics. VCH Cadmium Publishers, USA.

Saleh EF, Amel H, Hamad A, and Magdy EH (2011). Heavy metals accumulation in the mantle of the common cuttlefish Sepia pharaonis from the Arabian Gulf. Australian Journal of Basic and Applied Sciences, 5(6): 897-905.

Simmons TL, Andrianasolo E, McPhail K, Flatt P, and Gerwick WH (2005). Marine natural products as anticancer drugs. Molecular Cancer Therapeutics, 4(2): 333-342.

Singh S and Vuki V (2009). The sea hare fishery in Fiji islands. SPC Women in Fisheries Bulletin, 19: 17-18

Usero J, Regalado EG, and Gracia I (1997). Trace metals in the bivalve molluscs Ruditapes decussatus and Ruditapes philippinarum from the Atlantic Coast of Southern Spain. Environment International, 23(3), 291-298.

Wang WX and Ke C (2002). Dominance of dietary intake of cadmium and zinc by two marine predatory gastropods. Aquatic Toxicology, 56(3): 153-165.

Xing J and Chia FS (1997). Heavy metal accumulation in tissue/organs of a sea cucumber, Holothurialeucospilota. Journal of Hydrobiologia, 352(1): 17-23. 